\title{
Integrating WebQuest into Chemistry Classroom Teaching to Promote Students' Critical Thinking
}

\author{
Qing Zhou ${ }^{1 *}$, Leilei Ma ${ }^{1}, \mathrm{Na} \mathrm{Huang}^{1}$, Qian Liang ${ }^{1}$, Huiji Yue ${ }^{2}$, Tao Peng ${ }^{1}$ \\ ${ }^{1}$ School of Chemistry \& Chemical Engineering, Shaanxi Normal University, Xi'an, China \\ ${ }^{2}$ College of Physics and Information Technology, Shaanxi Normal University, Xi'an, China \\ Email: "zhouq@snnu.edu.cn
}

Received October $26^{\text {th }}, 2011$; revised November $20^{\text {th }}, 2011$; accepted December $15^{\text {th }}, 2011$

\begin{abstract}
The WebQuest is a student-centered, inquiry-oriented and project-based approach for teaching and learning that students use Web resources to learn school topics. This article reports on the design, implementation and evaluation of a WebQuest teaching approach for chemistry classroom teaching in improving the critical thinking of high school students. A pre- and post-test design was used where 4-month long-term WebQuest teaching approach with five chemical topics was offered to 50 high school students aged ranged from 16 to 17 years in Xidian Middle School attached to Xidian University in Shaanxi province of China. The California Critical Thinking Disposition Inventory (CCTDI) and the California Critical Thinking Skills Test (CCTST) were employed as data collection tools. Both CCTDI and CCTST scores of the participants showed significant differences $(p<0.05)$ between before and after WebQuest learning. The subscale scores of CCTDI showed significant differences in all aspects of dispositions toward critical thinking except open-mindedness and maturity. For CCTST subscales, the scores showed significant differences in analysis and evaluation but in inference. These findings add to the evidence that integrating WebQuest into science classroom teaching might be an effective way to develop high school students' critical thinking.
\end{abstract}

Keywords: Web-Based Learning; Critical Thinking; Computer-Based Learning; WebQuest; Chemistry Classroom Teaching

\section{Introduction}

\section{What Is a WebQuest?}

Classrooms have been provided with increasingly easier access to the Internet and teachers are challenged to create meaningful Web-based learning activities. With the rich array of resources such as up-to-date digital libraries, primary source documents, museum exhibits, and multimedia presentations about events, topics, and processes available on the Internet, educators have been optimistic about the value of exposing students to Web-based resources (McArthur \& Lewis, 1998). For example, exposure to current, authentic information uniquely available through Web sites can provide students with environments that support inquiry-based and constructivist learning (Oliver, 2000), improve student test performance, and develop broader forms of social, cultural, and intellectual capacity (Guile, 1998).

The WebQuest is a computer-based teaching and learning approach in which learners are actively involved in an activity or situation and use the Internet as a resource. This approach has students seek out information about a topic using Webbased resources. Thus, teachers send learners on a quest for information using the Word Wide Web. Likewise, Lamb and Teclehaimanot (2004) claimed that WebQuest is a student-centered and project-based approach for teaching and learning, which was rationally supported by a variety of theories, such as constructivist philosophy, critical and creative thinking, situated

*Corresponding author. learning environments, cooperative learning, and engaged learning.

The WebQuest has become prominent in many educational areas and has received considerable attention from teachers and educators since Dodge (1998) developed it. Dodge defined two types of WebQuests: short-term and long-term. Short-term WebQuest takes between one and three days to complete and generally introduce new ideas to students. Long-term WebQuest take longer than three days to complete and generally build on students' existing knowledge. According to Dodge, the instructional goal of a short-term WebQuest is the acquisition and integration of knowledge. At the end of a short-term WebQuest, lasting one to three class periods, a learner should have gained a significant amount of new information and made sense of it. The instructional goal of a long-term WebQuest, however, is to extend and refine the knowledge. After completing a long-term WebQuest, a learner should have examined a body of knowledge, transformed it in some way, and showed an understanding of the material or knowledge gained by creating any kind of work (for instance, defining a stance and defending it, designning new WebQuests, and constructing new problems or tasks) that others can respond to, online or offline.

Using WebQuests for inquiry-based learning represents an advance technology which requires students to practice strategies of searching, analyzing, and providing information. According to Dodge (2001) and March (2000), well-designed WebQuests - either short-term or long-term - consist of the following six critical attributes, including introduction, task, resources, processes, evaluation, and conclusion. In the introduction, the 
topic is usually launched with some interesting background information and a challenging authentic problem. Then a general description of the assigned task is presented in the task section. A set of Web sites that students can explore to complete the task are provided in the resource section or embedded in the process section, which provides detailed step-by-step procedures that students should follow to complete the task. The evaluation component describes the evaluation criteria, usually in the format of a rubric, which will be used to assess the students' work. Conclusion brings closure to the quest, reminds the learners about what they've learned, and encourages them to extend the experience into other domains.

\section{What Is Critical Thinking?}

There are many different approaches to subcategorizing thinking processes. For example, in Bloom's Taxonomy the cognitive domain is categorized into knowledge, comprehension, application, analysis, synthesis and evaluation (Bloom et al., 1956). Shiever (1991) and Baker and Baker (1994) provide a longer list which includes compare and contrast, problem identification and inferring. There are various definitions of critical thinking, but basically it relates to one's conscious effort in deciding what to do or to believe by focusing one's thought on it (Ennis \& Norris, 1989; Wade \& Tavris, 1993; Jonassen, 2000; Zerba, 2001). Richard Paul (1995) defines critical thinking as "disciplined, self-directed thinking which exemplifies the perfections of thinking appropriate to a particular mode or domain of thinking" (p. 526). Weinstein (2000) proposes a framework of critical thinking that includes: 1) skillful thinking; 2) responsible thinking; 3) non-routine thinking; 4) applying criteria; 5) self-correction; 6) sensitivity. According to Ennis (1987) [18], the critical thinking has three major parts: a) a critical thinking disposition; b) use of Bloom's (1956) higherorder thinking skills; and c) strategic problem solving abilities, and a critical thinker should demonstrate some abilities and dispositions. In his definition, Ennis distinguishes between skills and dispositions. Critical thinking skills include: analyzing arguments, judging credibility of sources, identifying the focus of the issue, and answering and asking clarifying and/or challenging questions. The dispositions, according to Ennis define the critical spirit. The critical spirit is what motivates critical thinkers to apply critical thinking abilities to the thinking of others and to their own thinking. Such dispositions include: Be prepared to determine and maintain focus on the conclusion or question, willing to take the whole situation into account, prepared to seek and offer reasons, amenable to being well informed, willing to look for alternatives, and withholding judgments when evidence and reasons are insufficient (Ennis, 1987, 1991; Kennedy, Fisher, \& Ennis, 1991).

\section{WebQuest and Critical Thinking?}

Students' critical thinking is a desirable outcome of learning, and the cultivation of critical thinking has been one of the primary goals of education. Since acquiring critical thinking is generally a longterm task, some scholars have suggested that we should start from students and employ teaching strategy to guide and induce student's critical thinking (Miller \& Malcolm, 1990; Yeh, 2001b; Yeh \& Tasy, 2001). Many researchers found that the utilization of computer and interactive multimedia assisted teaching systems can cultivate student's critical thinking (Fishman, 1994; Sparks \& Kuenz, 1993; Yeh, 2000; Yeh \&
Chen, 2002; Yeh et al., 2002a, 2002b). It has been suggested that one of the educational benefits associated with Web-based resources presentations is that in such tools knowledge is net-structured rather than traditionally linear structured information, so providing learners with greater flexibility of usage which can affect the individual's critical thinking (Andrea et al. 2005). Learning through Computer-Assisted Instruction (CAI) systems contributes to facilitating knowledge acquisition and improving attitude as well as behavioral tendencies.

The WebQuest characterized by Dodge (2001) is described as a deep learning that involves constructing new knowledge throughout a critical thinking process. Studies show that WebQuest learning is supported by four underlying constructs: critical thinking, knowledge application, social skills, and scaffolded learning (e.g., Brucklacher \& Gimbert, 1999; Dodge, 1995, 2001; Pohan et al., 1998); Some have embraced the WebQuest strategy in class teaching and believe that it is effective because it inspires critical thinking and contextualizes learning in a way that was not previously possible (Vidoni \& Maddux, 2002); Vidoni et al. (2002) compared the characteristics of WebQuests with Weinstein's critical thinking theory and concluded that "WebQuests meet all six of Weinstein's key elements in critical thinking and therefore are powerful tools for inspiring critical thinking skills in students" (p. 101). According to Crocco, Margaret Smith (2005), WebQuests can bring together important elements of some much touted approaches to teaching and learning, including critical thinking, cooperative learning, authentic assessment, and technology integration. Kundu, Rina and Bain, Christina (2006) described that teachers can design WebQuests to eliminate some traditional obstacles to art-based learning, expanding the types of inquiry that can be undertaken in classes and enabling students to master materials through problem solving and critical thinking.

Now days a lot of researches theoretically showed WebQuest could inspire students to think critically about the world, however there is very little empirical findings on the effects of WebQuests on development of students' critical thinking. The purpose of our study was to assess whether WebQuests in chemistry classroom teaching can improve the students' critical thinking.

\section{Methodology}

\section{Research Design}

A pre- and post-test experiment design was used to assess the effects of WebQuest learning in chemistry topics on high school students critical thinking dispositions and skills. Five chemistry topics for WebQuests were chosen in experiment, which were: "Ozone and hydrogen peroxide", "Reasons for the formation of acid rain, and its prevention", "Inorganic nonmetallic materials" and "Periodic table of elements", "The preparation and applications of sulfuric acid". Learners' levels of critical thinking were measured via the California Critical Thinking Dispositions Inventory (CCTDI) and the California Critical Thinking Skills Test (CCTST) (Facione, 1990, 1992).

The experiment was conducted in Xidian Middle School attached to Xidian University in Shaanxi province of China, which have the best teaching and learning networks environment: local area network, Internet environment, teaching management system and also share the resources of the Xidian University of Web resources. The number of spaces available in the computer room led to small differences in the number of students placed 
in each group to provide students with a personalized, interactive learning environment for cooperation.

\section{Procedure}

The authors developed the WebQuests for four chemistry teaching topics for the teacher and designed the details of the WebQuest activity. The teacher taught the chosen chemistry topics with the designed WebQuests and implementing the WebQuest activity in classroom. The students involved in WebQuests learning and were required to complete the CCTDI test in the first 15 minutes, and subsequently the CCTST for the next 45 minutes before and after the four month WebQuest learning. The pre- and post-test were administered and scored by the teacher.

Each designed WebQuest consisted of a Web courseware containing six attributes as Dodge (2001) and March (2000), which was introduction, project-based tasks, inquiry activity procedures to complete the task, a teacher collection of Webbased resources for exploration, evaluation criteria to assess the students' work and conclusion.

Take the topic "Ozone and hydrogen peroxide" for an example to illusion the WebQuest teaching. First, teacher launched the topic "Ozone and hydrogen peroxide" within a scenario that was attractive and fun to the students and the students received the technical instructions on navigating the WebQuest. Second, a complex task was assigned to the students. Teacher opened the courseware to guide students to browse the sites which related to the topic. Third, the participants worked in groups of five (one group had ten members) to complete the assigned tasks. The groups were allowed to browse the resources and use Web sites teacher-selected based on the learners' need to retrieve information, print materials with which to complete the tasks, and collaborate with each other at their convenience. Fourth, students explore their own under the guidance of teachers to achieve the task, evaluate themselves. Fifth, participants made oral presentations to compare and contrast what they have accomplished. All students exchanged their views and discussed. The last was class discussion and teachers' evaluation on students' work, and then make a conclusion.

The teacher was in the classroom at all times, occasionally interacting with students and answering questions related to the topics and also helped students with technical problems and answered computer related questions. During four month time, the teacher continued to lecture to the class the chemistry topics under the networks environment. The other four topics were lectured in the same mode of WebQuest project.

\section{Participants}

The subjects sampled in this study were 50 Grade 1 high school students from Xi'dian Middle School aged from 16 to 17 years in Xidian Middle School attached to Xidian University in Shaanxi province of China. They worked together through the WebQuest project, listened to the lectures, took notes, occasionally asked questions and discussed each other.

\section{Instruments}

\section{The California Critical Thinking Disposition Inventory}

The CCTDI, developed by Facione and Facione (1996), is a 75 item Likert scale tool with a Cronbach's alpha for the total scale of 0.92 . It has seven sub-scales: truth-seeking (12 items; alpha 0.71), open-mindedness (12 items; alpha 0.73 ), analyticity (11 items; alpha 0.72$)$, systematicity (10 items; alpha 0.74$)$, critical thinking and self-confidence (10 items; alpha 0.78), inquisitiveness (10 items; alpha 0.80 ) and maturity (10 items; alpha 0.75 ). Total points from the seven sub-scales determine an individual's critical thinking disposition. A person receiving less than a total of 280 points on the scale is taken to be of low disposition for critical thinking while the critical thinking tendency of a person receiving more than 350 points is high (Facione et al., 1994).

The Chinese version of the scale, which was translated and tested for psychometric properties by Luo and Yang in 2001, was used in this study. Offered by their report (2001), its Cronbach $\alpha$ is 0.86 , which is slightly lower than English version with Cronbach $\alpha$ being 0.91 . The validity index (CVI) ranged from 0.35 to 0.40 . Chinese and English CCTDI showed similarity for content validity and reliability for inquisitiveness (Luo \& Yang, 2001). In terms of multisampling analysis, there were equal forms across all subscales of the two versions.

\section{The California Critical Thinking Skills Test}

The CCTST was developed by Facione (1994), and is aimed at college students, but is probably usable for advanced and gifted high school students. It is a 34 -item standardized multiple-choice test, which measures the core of critical thinking skills, reports an overall score of an individual's critical thinking abilities and five subscales including analysis, evaluation, inference, deductive reasoning, and inductive reasoning.

The Chinese-version CCTST (2002) yields an overall score $(0-34)$ on critical thinking skills, Pearson $r=0.63, p<0.01$, $\mathrm{r} / 2=(0.75-0.80), p<0.01$, and three subscales: Analysis $(\mathrm{A})$ (0 - 9); Evaluation (E) $(0-14)$; and Inference (Inf) (0 - 11), which shows a good reliability, and good construct validity.

\section{Data Analysis}

The primary outcome measure was the students' critical thinking disposition and critical thinking skills. The data were analyzed using the SPSS16.0 for Windows versions. Paired t-test analysis was employed to compare CCTDI and CCTST scores before and after WebQuest project.

\section{Results}

\section{CCTDI}

According to Luo and Yang (2001), an overall score of 280 is the average point of critical thinking disposition, overall scores ranging from 280 to 350 indicate high-average and overall scores ranging from 210 to 280 indicate low-average. As shown in Table 1, the subjects demonstrated the critical thinking dispositions, with an overall mean score of 289.84 (SD = $18.64)$ in the pretest and $305.02(\mathrm{SD}=17.93)$ in the post-test, indicating that both pre- and post-test overall critical thinking disposition of the students attending are at high-average level. A statistically significant difference was found between preand post-test critical thinking disposition scores $\mathrm{t}=3.950(p<$ 0.001) (see Table 1) indicating that a long-term Webquests learning for chemistry topics can promote high school students' critical dispositions.

Table 2 shows the CCTDI subscale mean scores in the pre- 
and post-tests. According to Facione and Facione (1992), a subscale score less than 40 indicates weakness in a given critical thinking disposition. For the pre-test, there were three subscales scores of Truth-Seeking, Systematicity and Maturity were below 40, and four subscale scores of open-mindedness, analyticity, systematicity and inquisitiveness were above 40 . However, for the post-test CCTDI, all subscale means were above 40 . Indicating that the WebQuest project have a positive effect on the overall critical thinking disposition. As shown in Table 2, the scores of sub-scales between before and after WebQuest learning were statistically differences seen in the "truth-seeking, $\mathrm{t}=2.071(p<0.05)$, analyticity, $\mathrm{t}=2.166(p<0.05)$, systematicity, $\mathrm{t}=2.061(p<0.05)$, self-confidence, $\mathrm{t}=2.119(p<$ $0.05)$, inquisitiveness, $\mathrm{t}=2.091(p<0.05)$ ". No significant difference was found between the pre- and post-test for the subscale of open-mindedness, $\mathrm{t}=1.827(p>0.05)$ and maturity, $\mathrm{t}=0.387(p>0.05)$.

Figure 1 show the profiles for CCTDI subscale mean scores in the pre- and post-test. No matter in pre- or post-test, the subjects scored the weakest in the truth-seeking dispositions (see Figure 1). From high to low in terms of pre-test scores, the sequences were A $>\mathrm{S}>\mathrm{O}>\mathrm{M}>\mathrm{C}$ (Analyticity, Systematicity, Open-Mindedness, Maturity and Self-Confidence). With the same ranking scheme, the sequences for the post-test scores were $\mathrm{A}>$ $\mathrm{S}>\mathrm{O}>\mathrm{C}>\mathrm{M}$ (Analyticity, Systematicity, Open- Mindedness, Self-Confidence and Maturity). Compared to the pre- test, the score of self-confidence in the post-test was prompted by the WebQuest learning significantly. It indicated that the student-centered WebQuest approach can effectively promote high school students' self-confidence.

For both pre- and post-test, inquisitiveness scores is the highest while truth seeking the lowest. This finding is in agreement with those of other researchers such as Sanchez et al. (1994), Facione et al. (1995), Colucciello (1997), Walsh and Hardy (1999), Ip et al. (2000), and Yeh and Chen (2003). Even though the subjects in this study have the lowest score in

Table 1.

Comparison of pre- and post-test on CCTDI scores.

\begin{tabular}{ccccc}
\hline & $\mathrm{n}$ & $\mathrm{X} \pm \mathrm{sd}$ & $\mathrm{t}$ & $p$ \\
\hline Pre-test & 50 & $289.84 \pm 18.64$ & & \\
Post-test & 50 & $305.02 \pm 17.93$ & & 0.000 \\
\hline
\end{tabular}

Table 2.

Comparison of pre- and post-test on CCTDI subscale scores $(\mathrm{N}=50)$.

\begin{tabular}{ccccc}
\hline Sub-scale & Pre-test $\mathrm{X} \pm \mathrm{sd}$ & Post-test $\mathrm{X} \pm \mathrm{sd}$ & $\mathrm{t}$ & $p$ \\
\hline Truth-seeking & $37.39 \pm 6.49$ & $40.19 \pm 6.39$ & $-2.071^{*}$ & 0.045 \\
Open-mindedness & $41.52 \pm 5.58$ & $43.58 \pm 4.61$ & -1.827 & 0.075 \\
Analyticity & $45.04 \pm 6.64$ & $47.12 \pm 5.71$ & $-2.166^{*}$ & 0.036 \\
Systematicity & $42.06 \pm 5.59$ & $44.58 \pm 5.81$ & $-2.061^{*}$ & 0.045 \\
Self-confidence & $38.75 \pm 5.89$ & $40.98 \pm 5.59$ & $-2.119^{*}$ & 0.040 \\
Inquisitiveness & $45.68 \pm 5.96$ & $48.14 \pm 5.51$ & $-2.091^{*}$ & 0.043 \\
Maturity & $39.88 \pm 6.08$ & $40.44 \pm 5.82$ & -0.387 & 0.701 \\
\hline
\end{tabular}

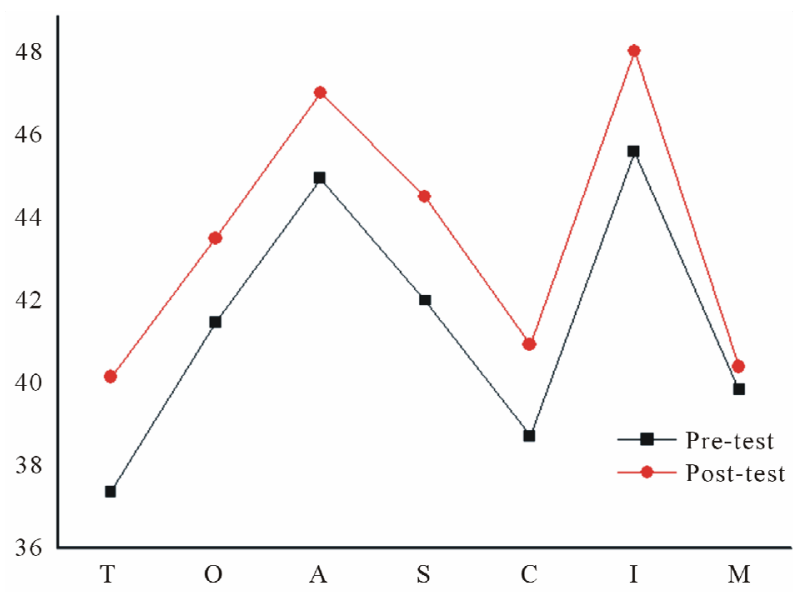

Figure 1.

Mean scores of CCTDI's seven subscales for two times. Note: $\mathrm{T}=$ Truth-Seeking; $\mathrm{O}=$ Open-Mindedness; $\mathrm{A}=$ Analyticity; $\mathrm{S}=$ Systematicity; $\mathrm{C}=$ Self-Confidence; $\mathrm{I}=$ Inquisitiveness; $\mathrm{M}=$ Maturity.

truth-seeking, they made significant improvements from pre- to post-test. This finding indicates that the 4-month WebQuest program might help the students to seek the truth and be willing to solve problems using critical thinking instead of relying on authoritatively correct answers.

\section{CCTST}

As shown in Table 3, the critical thinking skills have an overall mean score of $10.57 \pm 3.10$ in the pre-test and $12.53 \pm$ 2.97 in the post-test. Compared with the data of the CCTST manual provided by Luo and Yang (2002) $(\mathrm{M}=15.98, \mathrm{SD}=$ $4.457, \mathrm{n}=718$ ), the critical thinking skills of the students attending both the pre-test and post-test are at low level. However, the post-test scores of critical thinking skills compared with pre-survey ones had certainly enhanced, and t-test also showed that there are statistically significant differences between the overall scores for the two tests $t=2.859(p<0.01)$ (see Table $3)$. We also found that the relationship of three skills' scores on the CCTST (see Figure 2), no matter in pre- or post-test the sequences were $\mathrm{E}>\mathrm{A}>\operatorname{Inf}$ (Analysis, Evaluation, Inference). Compared to the pre-test, the subjects in the post-test had higher scores of all three skills (Figure 2). There are statistically significant differences in the subscales of analysis, $\mathrm{t}=$ $2.083(p<0.05)$ and evaluation, $\mathrm{t}=2.202(p<0.05)$. However no significant differences were found between the pre- and post-test for inference, $t=1.550(p>0.05)$ (see Table 4). The results showed that students' analysis and evaluation ability can be promoted by WebQuest learning.

\section{Conclusion}

Comparing the results before and after the WebQuest learning, there exist significant differences in both critical thinking disposition and critical thinking skills. After the WebQuest learning, for the critical thinking disposition, there were significant differences in truth-seeking, analyticity, systematicity, self-confidence, and inquisitiveness. Even though they made significant improvements in subscales of open-minded and maturity from pre- to posttest, no significant differences were found. And as well as the critical thinking skills, the results of 
Table 3.

Comparison of pre- and post-test on CCTST scores.

\begin{tabular}{ccccc}
\hline & $\mathrm{n}$ & $\mathrm{X} \pm \mathrm{sd}$ & $\mathrm{t}$ & $p$ \\
\hline Pre-test & 50 & $10.57 \pm 3.10$ & & \\
Post-test & 50 & $12.53 \pm 2.97$ & $-2.859^{* *}$ & 0.007 \\
\hline
\end{tabular}

Note: $p<0.01$.

Table 4.

Comparison of pre- and post-test on CCTST subscale scores $(\mathrm{N}=50)$.

\begin{tabular}{ccccc}
\hline Sub-scale & Pre-test $\mathrm{X} \pm \mathrm{sd}$ & Post-test $\mathrm{X} \pm \mathrm{sd}$ & $\mathrm{t}$ & $\mathrm{p}$ \\
\hline Analysis & $3.59 \pm 1.51$ & $4.23 \pm 1.21$ & $-2.083^{*}$ & 0.043 \\
Evaluation & $4.45 \pm 1.69$ & $5.23 \pm 1.62$ & $-2.202^{*}$ & 0.033 \\
Inference & $2.53 \pm 1.32$ & $3.07 \pm 1.44$ & -1.550 & 0.129 \\
\hline
\end{tabular}

Note: $p<0.05$.

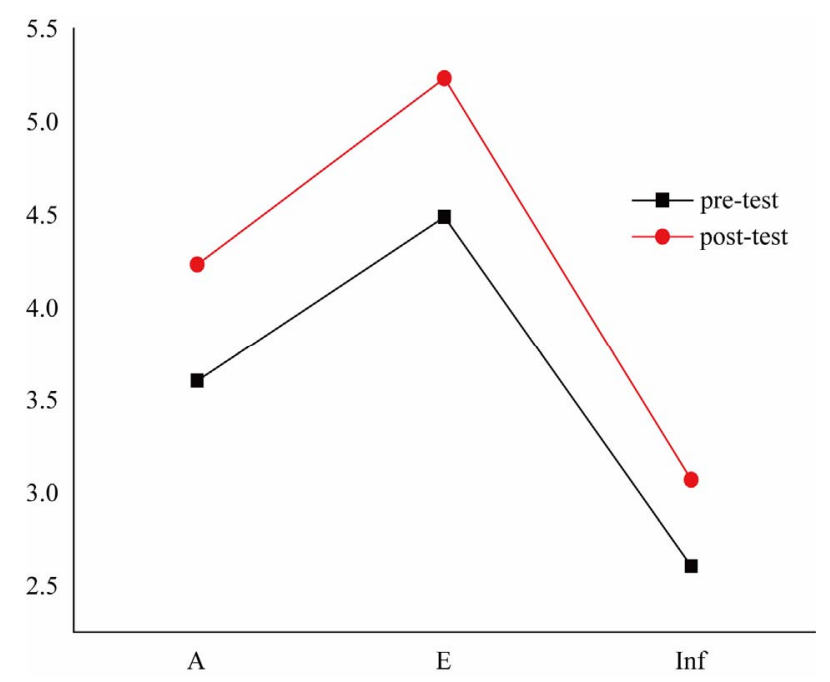

Figure 2.

Mean scores of CCTST's three subscales for two times. Note: A = Analysis; $\mathrm{E}=$ Evaluation; $\mathrm{Inf}=$ Inference.

subscales showed significant differences in analysis and evaluation with the exception of inference. Overall, the results corroborate findings from other studies (Yeh \& Chen, 2003) that found critical thinking is enhanced when WebQuest are used in chemistry class teaching.

Students' critical thinking is a desirable outcome of learning, and the cultivation of critical thinking has always been one of the primary goals of education. Contrast to the passive receiving knowledge from teacher-centered class, WebQuest which is computer-based teaching and learning approach with internet resources provides student with active, student-centered learning. The qualitative data of this paper suggest that integrating Webquests into science classroom teaching might an effective approach to promote students' critical thinking.

\section{Acknowledgements}

We gratefully acknowledge for the support and collaboration of the Class 4 Grade 1 high school participating students and the chemistry teachers in the Xidian Middle School attached to Xidian University, China.

\section{REFERENCES}

Baker, A., \& Baker, J. (1994). Developing thinking skills: Using children's literature. Melbourne, VIC: Eleanor Curtain Publishing.

Bloom, B. S., Engelhart, M. D., Furst, E. J., Hill, W. H., Krathworld, D. R., \& David M. (1956). Taxonomy of educational objectives: The classification of educational goals. Handbook 1: Cognitive domain. New York, NY: Longman.

Bloom, B. S. (1956). Taxonomy of educational objectives. New York, NY: Longman.

Brucklacher, B., \& Gimbert, B. (1999). Role-playing software and WebQuests: What's possible with cooperative learning and computers. Computers in the Schools, 15, 37-48. doi:10.1300/J025v15n02 05

Calcaterra, A., Antonietti, A., \& Underwood, J. (2005). Cognitive style, hypermedia navigation and learning. Computers \& Education, 44, 441-457. doi:10.1016/j.compedu.2004.04.007

Crocco, M. S., \& Cramer, J. (2005). Women, WebQuests, and controversial issues in the social studies. Social Education, 69, 143-148.

Dodge, B. (1997). Some thoughts about WebQuest. URL (last checked 5 May 1997). http://WebQuest.sdsu.edu/about_WebQuests.html

Dodge, B. (1995). WebQuests: A technique for internet-based learning. Distance Educator, 1, 10-13.

Dodge, B. (2001). Focus: Five rules for writing a great WebQuest. Learning and Leading with Technology, 28, 6-9.

Ennis, R. H. (1987). A taxonomy of critical dispositions and abilities. In J. B. Baron, \& R. J. Sternberg (Eds.), Teaching thinking skills: Theory and practice (pp. 9-26). New York: Freeman.

Ennis, R. H., \& Norris, S. (1989). Evaluating critical thinking. Pacific Grove, CA: Midwest Publications.

ESI Princeton (2001). Environmental and organismal properties of heat transfer and absorption. URL (last checked 20 July 2001). http://www.woodrow.org/teachers/esi/2001/Princeton/Project/zerba/

Facione, P. A. (1990). Critical thinking: A statement of expert consensus for purposes of educational assessment and instruction-The Delphi report. Millbrae, CA: California Academic Press.

Facione, P. A., \& Facione, N. C. (1992). The California critical thinking disposition inventory. Millbrae, CA: California Academic Press.

Facione, P. A., \& Facione, N. C. (1994). The California critical thinking skills test: Test manual. Millbrae, CA: California Academic Press.

Facione, P. A., Facione, N. C., \& Sanchez, C. A. (1994). Critical thinking disposition as a measure of competent clinical judgement: The development of the CCTDI. Journal of Nursing Education, 33, 345350.

Facione, P. A., Sanchez, C. A., Facione, N. C., \& Gainen, J. (1995). The disposition toward critical thinking. The Journal of General Education, 44, 1-25.

Facione, N. C., \& Facione, P. A. (1996). Externalizing the critical thinking in clinical judgement. Nursing Outlook, 44, 129-136. doi:10.1016/S0029-6554(06)80005-9

Fishman, D. J. (1994). Development and evaluation of computer-assisted video program teaching cancer chemotherapy to nurses. Computer in Nursing, 2, 16-23.

Guile, D. (1998). Information and communication technology and education. London: University of London Press.

Ip, W. Y., Lee, D. T., Lee, I. F., Chau, J. P., Wootton, Y. S., \& Chang, A. M. (2000). Disposition towards critical thinking: A study of Chinese undergraduate nursing students. Journal of Advanced Nursing, 32, 84-90. doi:10.1046/j.1365-2648.2000.01417.x

Jonassen, D. (2000). Computers as mindtools for schools: Engaging critical thinking (2nd ed.). Upper Saddle River, NJ: Prentice Hall.

Kennedy, M., Fisher, M. B., \& Ennis, R. H. (1991). Critical thinking: Literature review and needed research. In L. Idol, \& B. Fly Jones (Eds.), Educational values and cognitive instruction: Implications for reform (pp. 11-40). Hillsdale, NJ: Lawrence Erlbaum.

Kundu, R., \& Bain, C. (2006). WebQuests: Utilizing technology in a constructivist manner to facilitate meaningful preservice learning. Art Education, 59, 6-11. 
Lamb, A., \& Teclehaimanot, B. (2004). WebQuest: Definitions and foundations. URL (last checked 22 October 2007).

http://www.eduscapes.com/sessions/travel/define.htm\#2

Luo, Q. X., \& Yang, X. H. (2002). Revision for the Chinese-version CCTST. Psychology Science, 25, 740-741.

March, T. (2000). WebQuests 101. Multimedia Schools, 7, 55-58.

Margaret, L. C. (1997). Critical thinking skills and dispositions of baccalaureate nursing students-A conceptual model for evaluation. Journal of Professional Nursing, 13, 236-245.

McArthur, D., \& Lewis, M. (1998). Untangling the web: Applications of the internet and other information technologies to higher learning. Santa Monica, CA: Rand.

Miller, M. A., \& Malcolm, N. S. (1990). Critical thinking in the nursing curriculum. Nursing \& Health Care, 11, 67-73.

Oliver, K. (2000). Methods for developing constructivist learning on the web. Educational Technology, 40, 5-16.

Paul, R. (1995). Critical thinking: How to prepare students for a rapidly changing world. Santa Rosa, CA: Foundation for Critical Thinking.

Pohan, C., \& Mathison, C. (1998). WebQuests: The potential of internet based instruction for global education. Social Studies Review, 37, 91-93.

Luo, Q. X., \& Yang, X. H. (2001). Revision for the Chinese-version CCTDI. Psychology Develop and Education, 3, 47-51.

Sanchez, C. A., Reise, S. P., Facione, P. A., \& Facione, N. C. (1994). Personality correlates of critical thinking in college students. The 102nd Annual Conference of the American Psychological Association, Los Angeles, 12-16 August 1994.

Shiever, S. W. (1991). A comprehensive approach to teaching thinking. Boston, MA: Allyn \& Bacon, Inc.

Sparks, S. M., \& Kuenz, M. A. (1993). Interactive instruction in nursing and other health sciences: Review of evaluation instruments. Be- thesda, MD: National Institutes of Health, National Library of Medicine.

Vidoni, K. L., \& Maddux, C. D. (2002). WebQuests: Can they be used to improve critical thinking skills in students. Computers in the Schools, 19, 101-117. doi:10.1300/J025v19n01 09

Wade, C., \& Tavris, C. (1993). Critical and creative thinking: The case of love and war. New York, NY: Harper Collins College Publishers.

Walsh, C. M., \& Hardy, R. C. (1999). Dispositional differences in critical thinking related to gender and academic major. Journal of Nursing Education, 38, 149-155.

Weinstein, M. (2000). A framework for critical thinking. High School Magazine, 7, 40-43.

Yeh, M. L. (2000). Critical thinking and computer. Nursing, 4, 15-26.

Yeh, M. L. (2001). Critical thinking and teaching strategy. New Taipei Journal of Nursing, 2, 7-12.

Yeh, M. L., \& Tasy, H. L. (2001). Debating and teaching strategy. Journal of Nursing, 48, 65-70.

Yeh, M. L., \& Chen, H. H. (2002). Developing and testing a computerassisted instruction program with interactive videodisc systems. Journal of Nursing, 49, 55-60.

Yeh, M. L., Chen, H. H. \& Chang, C. H. (2002a). Developing a computer-assisted instruction CD-ROM program for Nursing. Formosa Journal of Medicine, 6, 944-950.

Yeh, M. L., Chen, H. H., \& Chang, H. F. (2002b). The effect of the Internet assisted smoking cessation program among ado-lescents. Formosa Journal of Medicine, 6, 648-660.

Yeh, M. L., \& Chen, H. H. (2003). Compare affective dispositions toward critical thinking across Chinese and American baccalaureate nursing students. Nursing Research, 11, 39-46. doi:10.1097/01.JNR.0000347617.29413.96 